\title{
Effects of Macondo Oil on Phytoplankton from Grand Isle, Louisiana
}

\section{Jie Li ${ }^{1}$, Robert R Bidigare ${ }^{2}$ and Edward A Laws ${ }^{1 *}$}

${ }^{1}$ Department of Environmental Sciences, College of the Coast and Environment, Louisiana State University, Baton Rouge, LA 70803, USA

${ }^{2}$ Hawaii Institute of Marine Biology, University of Hawaii, PO Box 1346, Kaneohe, HI 96744, USA

\begin{abstract}
Bioassays were performed on phytoplankton communities from the coastal waters at Grand Isle, Louisiana from February through August 2013 to determine the impact of the water-accommodated fraction of unweathered Macondo well oil on the growth rates and taxonomic composition of the phytoplankton. Pigment analysis indicated that diatoms dominated the natural phytoplankton communities, and with one exception, diatoms were the only class of phytoplankton that grew in control cultures or in artificial seawater amended with the water-accommodated fractions of Macondo well oil at a series of concentrations from 0.1 to $19.2 \mathrm{mg} \mathrm{L}^{-1}$. The growth rates of diatoms were enhanced by roughly $10 \%$ at oil concentrations $\leq 0.6 \mathrm{mg} \mathrm{L}^{-1}$ but were reduced by up to $30 \%$ at concentrations $\geq 1.0 \mathrm{mg} \mathrm{L}^{-1}$. Ratios of fucoxanthin to chlorophyll a were positively correlated with oil concentrations, an indication that there was some adjustment of the characteristics of the light-harvesting antennae of the diatoms in response to the stress of the oil.
\end{abstract}

Keywords: Macondo oil; Phytoplankton; Water-accommodated fraction; Pigments; Growth rates

\section{Introduction}

The input of oil to the ocean from all sources has been estimated to total roughly 1.3 million tonnes $y^{-1}[1]$. The source of about half of that oil is believed to be several hundred naturally occurring seeps, most of which occur near continental coastlines. The remaining inputs are traceable to anthropogenic sources, and historically the most noteworthy of those inputs have involved crude oil. The quantity of oil discharged to the ocean annually as a result of tanker accidents, for example, averaged several hundred thousand tonnes during the 1970s and 1980s. Those discharges declined dramatically following the grounding of the Exxon Valdez in 1989 and passage by the United States Congress of the Oil Pollution Act of 1990. Annual discharges from tanker accidents averaged only 21,000 tonnes from 2000 to 2009 and have averaged only 5000 tonnes since 2010 [2]. Unfortunately, discharges of only a few hundred tonnes of oil can have devastating effects on marine ecosystems if the oil is discharged close to shore and is mixed by physical processes into the water and sediments $[3,4]$.

Although much of the literature on the impacts of oil spills on marine organisms has concerned macrofauna [5-8], the impact of spilled oil on plants is potentially quite serious because plants are important determinants of the physical stability and resilience of coastal marine ecosystems [3], and of course photosynthetic organisms are responsible for producing much of the organic carbon that provides biomass and energy for the heterotrophic community. Although macrophytes such as Spartina alterniflora and Juncus roemerianus account for much of the resilience of salt marshes to perturbations such as hurricane storm surges, carbon and sulfur stable isotope studies have shown that the organic carbon in primary consumers in the Great Sippewissett marsh in Massachusetts and the Sapelo Island marsh in Georgia are derived about equally from Spartina and phytoplankton $[9,10]$. Assessment of the impact of spilled oil on coastal marine and wetland food chains therefore requires consideration of the effects of the oil on phytoplankton communities.

Several previous studies have examined the effects on individual phytoplankton species of crude oil [11-17], various components of crude oil [18-23], and refined oil products [23-27]. The general implication of these studies has been that low concentrations of crude oil or components thereof stimulate photosynthesis by some species $[13,19,23]$ but have no positive effect on other species. High concentrations are invariably inhibitory. The extent of inhibitory effects depends very much on the composition of the oil. Analogous studies have examined the effects on natural phytoplankton communities of crude oil [28-34], pyrene [35], and fuel oil [23,29,36,37]. The results of those studies have been generally consistent with the studies on individual species. Low concentrations of oil apparently have a positive effect on at least some components of natural phytoplankton communities [29-31,37], whereas high concentrations are invariably inhibitory. Remarkably, Varela et al. [36] detected few if any adverse effects of the Prestige oil spill on plankton communities off the northwestern coast of Spain, although the sunken tanker released an estimated 63,000 tons of fuel oil and polluted thousands of kilometers of coastline. The goal of the present study was to determine the effect of crude oil from the Macondo oil well in the Mississippi Canyon block 252 of the Gulf of Mexico on natural coastal marine phytoplankton communities. Macondo oil is a light crude oil with an API gravity of 40 [38], and its solubility in seawater at $25^{\circ} \mathrm{C}$ should therefore exceed $55 \mathrm{mg} \mathrm{L}^{-1}$ [39].

\section{Materials and Methods}

\section{Sample collection}

Coastal water samples were collected in clean polycarbonate bottles from just below the surface at Grand Isle, Louisiana $\left(29.2278^{\circ} \mathrm{N}\right.$, $90.0122^{\circ} \mathrm{W}$ ) during the months of February, March, April, May, July, and August of 2013. The water was passed through 35-micron mesh netting to eliminate large zooplankton grazers. Temperature was recorded to the nearest $0.1^{\circ} \mathrm{C}$ at the time of collection with a digital thermometer. Salinity was measured to the nearest 1 in the laboratory with an Extech model RF20 refractometer. Water samples were transported promptly to the laboratory for the initiation of growth rate measurements.

*Corresponding author: Edward A Laws, Department of Environmental Sciences, College of the Coast and Environment, Louisiana State University, Baton Rouge, LA 70803, USA, Tel: 12255788800; E-mail: edlaws@Isu.edu

Received May 04, 2017; Accepted May 08, 2017; Published May 13, 2017

Citation: Li J, Bidigare RR, Laws EA (2017) Effects of Macondo Oil on Phytoplankton from Grand Isle, Louisiana. J Environ Anal Toxicol 7: 468. doi: 10.4172/2161 0525.1000468

Copyright: $\odot 2017 \mathrm{Li} \mathrm{J}$, et al. This is an open-access article distributed under the terms of the Creative Commons Attribution License, which permits unrestricted use, distribution, and reproduction in any medium, provided the original author and source are credited. 
Citation: Li J, Bidigare RR, Laws EA (2017) Effects of Macondo Oil on Phytoplankton from Grand Isle, Louisiana. J Environ Anal Toxicol 7: 468. doi: 10.4172/2161-0525.1000468

Page 2 of 7

\section{Sample preparation and analysis}

Two $\mathrm{mL}$ aliquots of sample water were added to $300-\mathrm{mL}$, clearglass biochemical oxygen demand (BOD) bottles containing artificial seawater medium (Instant Ocean ${ }^{\circledR}$ ) amended with $\mathrm{f} / 2$ nutrients $[40,41]$ and various concentrations of Macondo oil. The algal cultures were grown at a temperature of $19-20^{\circ} \mathrm{C}$ on a $12: 12$ light:dark (L:D) cycle with irradiance provided by daylight fluorescent lamps at an intensity of $300 \mu \mathrm{mol}$ photons $\mathrm{m}^{-2} \mathrm{~s}^{-1}$, which is adequate to saturate phytoplankton growth rates [42-44]. The light intensity was measured with a QSL-2100 quantum scalar laboratory radiometer. The bottles were agitated three times a day to ensure that the cultures were well mixed and that the algae did not adhere to the bottom of the bottles.

The oil consisted of the water-accommodated fractions (WAFs) of unweathered source oil from the Macondo well collected by BP from a riser pipe aboard the drillship Discoverer Enterprise connected to the damaged wellhead of the Deepwater Horizon rig on May 20, 2010. The oil was stored in the laboratory in an opaque screw-cap vial to minimize degassing of the volatile components. WAFs were prepared with oil concentrations of $0.1,0.3,0.6,1.2,2.4,4.8,9.6$, and $19.2 \mathrm{mg} \mathrm{L}^{-1}$. The basic procedure for preparing the WAFs was to layer a known amount of oil onto a known volume of $\mathrm{f} / 2$ medium in two-liter glass reagent bottles. The headspace-to-vessel ratio was maintained at about $20 \%$. The oil-and-water was then mixed slowly (about $200 \mathrm{rpm}$; no vortex) with magnetic stirrers for $24 \mathrm{~h}$ to achieve stability. After 24 hours, the liquid phase (the WAF) was siphoned from underneath the film of oil at the surface, care being taken not to disturb the oil. The WAFs were used immediately to minimize the effects of bacterial activity during storage [45]. In all experiments, the control consisted of $\mathrm{f} / 2$ medium containing no oil. All treatments, including the control, were run in triplicate.

The number of cells in the BOD bottles was monitored twice daily using optical density (OD) as a metric of cell numbers $[46,47]$. The OD measurements were made with a Cary model 50 UV-Visible Spectrophotometer at a wavelenth of $750 \mathrm{~nm}$ and pathlength of $1 \mathrm{~cm}$. The signal averaging time was 3 seconds. OD readings were recorded three times whenever a bottle was sampled. Fresh, filtered medium was used for blank measurements.

We checked the proportionality between OD readings and cell counts by counting cells with a model Z1 Beckman Coulter particle counter. The samples were shaken vigorously to break up colonies. Blank counts (filtered artificial seawater) were subtracted from all counts. We found that cell counts were directly proportional to OD readings below an OD of approximately 0.4 . If the OD readings exceeded 0.4 , the samples were diluted to bring the OD reading below 0.4. Growth rates were calculated from the slope of a straight line fit to the natural logarithm of the OD readings versus time within the time interval where the relationship was linear.

Pigment concentrations were measured in February, March, May, July, and August of 2013. At the end of log-phase growth, samples of WAFs from two of the three bottles were collected and filtered individually onto 25 -mm-diameter Whatman GF/F glass-fiber filters at a vacuum pressure of $160 \mathrm{~mm} \mathrm{Hg}$. The filters were folded twice and wrapped in aluminum foil to exclude air. The filters were then stored in a freezer at $-15^{\circ} \mathrm{C}$ prior to pigment analysis. Aliquots of the initial water samples were filtered and processed in an identical manner. The pigment analyses were carried out with a high-performance liquid chromatograph (HPLC) using the methodology described by Bidigare, et al. [48]. The pigments were extracted in $3 \mathrm{~mL}$ of HPLC-grade acetone in culture tubes with $50 \mu \mathrm{L}$ of an internal standard (canthaxanthin) at $4^{\circ} \mathrm{C}$ for 24 hours and then hand ground in acetone using a glass-glass tissue homogenizer to ensure complete extraction of all pigments from phytoplankton cells. The extracts were then vortexed and centrifuged for five minutes to remove cellular and filter debris.

Mixtures of 1-mL extracts plus $0.3 \mathrm{~mL}$ of HPLC grade water were prepared in opaque auto-sampler vials, and a $200-\mu \mathrm{L}$ aliquot was injected onto a Varian 9012 HPLC system equipped with a Varian 9300 auto-sampler, a Timberline column heater $\left(26^{\circ} \mathrm{C}\right)$, and a Waters Spherisorb $^{\star} 5-\mu \mathrm{m}$ ODS-2 analytical $(4.6 \times 250 \mathrm{~mm})$ column and corresponding guard cartridge $(7.5 \times 4.6 \mathrm{~mm})$. Pigments were detected with a ThermoSeparation Products UV2000 detector $\left(\lambda_{1}=436 \mathrm{~nm}\right.$, $\left.\lambda_{2}=450 \mathrm{~nm}\right)$. A ternary solvent system was used for pigment analysis: Eluent A (methanol:0.5 M ammonium acetate, 80:20, v/v), Eluent B (acetonitrile:water, 87.5:12.5, v/v), and Eluent C (100\% ethyl acetate) Solvents A and B contained an additional $0.1 \%$ of 2,6-di-ter-butylp-cresol $(0.01 \%$ butylated hydroxytoluene, w/v; Sigma-Aldrich) to prevent the conversion of chlorophyll $a$ into chlorophyll $a$ allomers. The linear gradient used for pigment separation was a modified version of the Wright, et al. [49] method: time zero ( $90 \% \mathrm{~A}, 10 \% \mathrm{~B}$ ); one minute (100\% B); 11 minutes (78\% B, 22\% C); 27.5 minutes (10\% B, 90\% C); 29 minutes (100\% B); 30 minutes (100\% B); 31 minutes (95\% A, 5\% B); 37 minutes $(95 \% \mathrm{~A}, 5 \% \mathrm{~B})$; and 38 minutes $(90 \% \mathrm{~A}, 10 \% \mathrm{~B})$.

To calculate the fraction of white light absorbed by the various photosynthetic pigments at the end of the incubations, we used the in vivo absorption spectra of the pigments reported by Fujiki and Taguchi [50], who generated their data from the absorption spectra of pure pigment standards and then wavelength-shifted the spectra to match the in vivo absorption spectra of diatom cultures using the methods described by Bidigare et al. [51].

The significance of oil effects on dependent variables such as growth rates was judged on the basis of correlation analysis (Spearman) and one-way analysis of variance (ANOVA). Oil effects were judged to be statistically significant if the associated type I error rates $(p)$ were less than 0.05 .

\section{Results}

Water temperatures at the time of collection ranged from $17.4^{\circ} \mathrm{C}$ in March to $28.3^{\circ} \mathrm{C}$ in July. Salinities ranged from 14 in July to 21 in March. Reliable OD readings were obtained in all months except February, when lack of familiarity with the spectrophotometer resulted in an unacceptable level of noise in the data.

For the other months, we calculated the growth rates of the phytoplankton in the oil treatments during each month as a percentage of the control growth rates during the same month and then averaged the percentages over all five months. The averages of these percentages were significantly correlated $(r=-0.9, p=0.0045)$ with oil concentrations (Figure 1). An ANOVA revealed that the rates at oil concentrations $\leq 0.6 \mathrm{ppm}$ and $\geq 1.2 \mathrm{ppm}$ were significantly different $(p=0.0067)$. The former exceeded the latter by about $25 \%$.

The pigments found in all samples included chlorophyll $a$ (CHLA), fucoxanthin (FUCO), chlorophyll $c$ (CHLC), $\beta$-carotene ( $\beta$-CAR), diadinoxanthin (DDX) and diatoxanthin (DTX). The implication is that in most cases the phytoplankton community consisted almost entirely of diatoms (Table 1). However, some of the initial samples also contained small concentrations of $\alpha$-carotene, alloxanthin, chlorophyll $b$, lutein, peridinin, and zeaxanthin. Lutein is diagnostic for chlorophytes, and peridinin is diagnostic for dinoflagellates (Table 1). The absence of prasinoxanthin, 19'-butanoyloxyfucoxanthin, and 


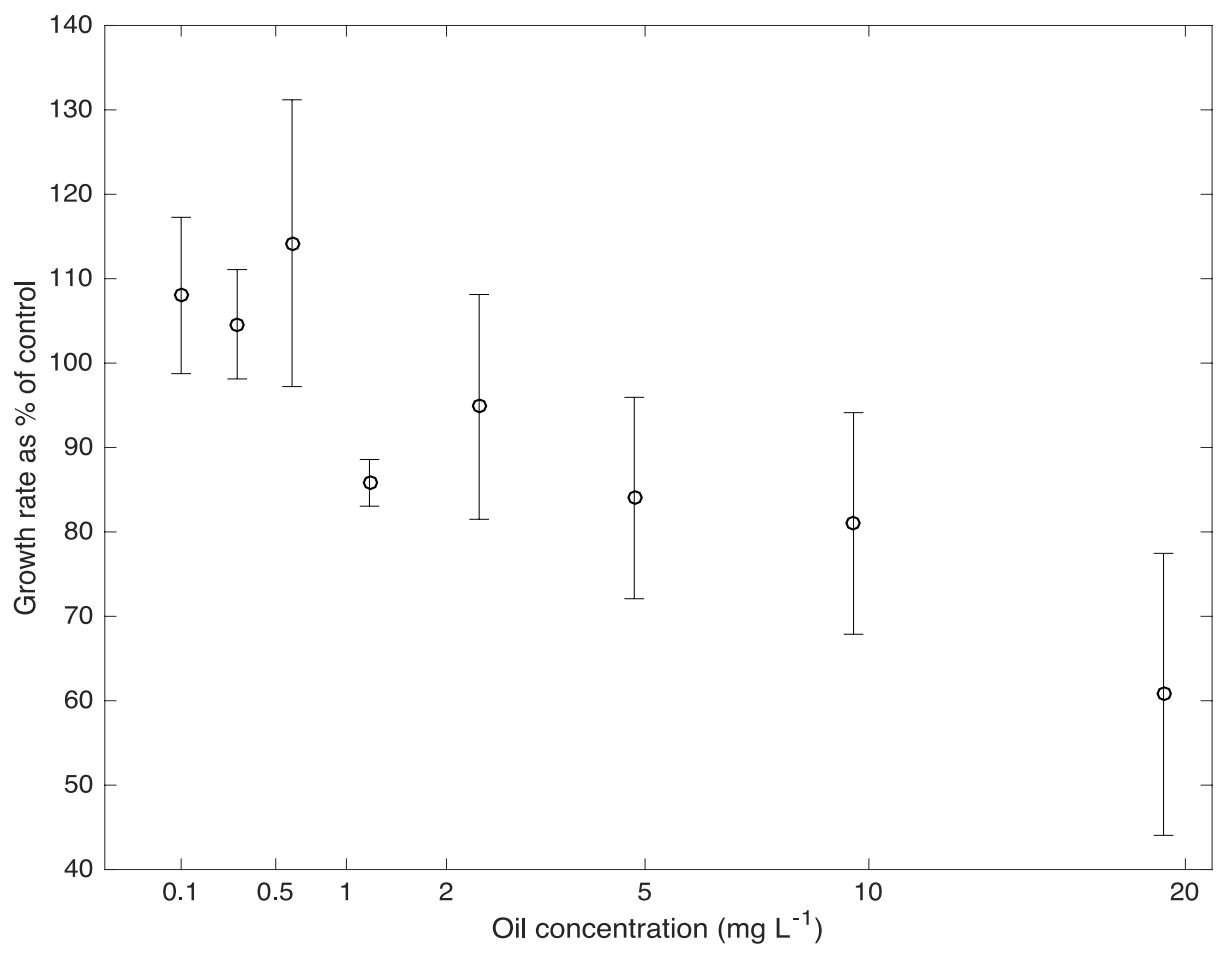

Figure 1: Phytoplankton growth rates as a percent of control growth rates versus oil concentrations from 0.1 to 19.2 ppm. Error bars are standard errors of the mean values at each oil concentration.

$19^{\prime}$-hexanoyloxyfucoxanthin rules out prasinophytes, pelagophtytes, and prymnesiophytes, respectively (Table 1 ). The initial samples that contained zeaxanthin also contained lutein, chlorophyll $b$, $\alpha$-carotene, and $\beta$-carotene, the implication being that the zeaxanthin was associated with chlorophytes or a combination of chlorophytes and cyanobacteria (Table 1). The presence of alloxanthin, $\alpha$-carotene, and chlorophyll $c$ in the initial samples is consistent with those samples containing cryptophytes (Table 1). At the end of the incubations, the samples, including the control samples, contained no detectable a-carotene, alloxanthin, lutein, or peridinin. The fact that zeaxanthin was present at the end of the incubations in all of the treatments in February implied that cyanobacteria were present (Table 1). However, the average ratio of zeaxanthin to CHLA was $0.075 \pm 0.017$, which is only about $15 \%$ of the same ratio in cyanobacteria [52]. The implication is that diatoms dominated the cultures by the end of the incubations in all cases.

Both the CHLC/CHLA ratio $(0.100 \pm 0.020)$ and the $\beta$-CAR/ CHLA ratio $(0.0188 \pm 0.0058)$ were remarkably constant at the end of the incubations. Neither ratio was significantly correlated with oil concentrations ( $p=0.76$ and $p=0.92$, respectively).

Calculations of the percentage of white light absorbed by pigments at the end of the incubations indicated that CHLA and FUCO together accounted for $76-82 \%$ of visible light absorption. The ratios of FUCO to CHLA at the end of the incubations were positively correlated with oil concentrations ( $r=0.85, p=0.0041)$ (Figure 2$)$, and the percentages of visible light absorbed by CHLA and FUCO were approximately mirror images of each other (Figure 3).

\section{Discussion}

A number of previous investigators have reported stimulatory effects of oil on phytoplankton growth or photosynthesis at low oil concentrations, typically less than $1 \mathrm{mg} \mathrm{L}^{-1}$, and inhibition at high oil concentrations $[13,15,19,23,29-31]$. The toxicity of crude oil to phytoplankton results from a variety of effects that reflect the complex composition of crude oil. The toxicity of individual compounds is positively correlated with the solubility of the compounds in water, and as a result refined oil is more toxic than crude oil [53]. Results of numerous studies have indicated that the toxicity of lipophilic compounds reflects their effects on the cytoplasmic membrane and/or membrane-embedded enzymes [54]. Polycyclic aromatic hydrocarbons appear to be particularly toxic [15]. Effects include cell lysis, loss of membrane integrity, changes in lipid-protein interactions, modifications of membrane fluidity, decreases in intracellular $\mathrm{pH}$, and changes in membrane structure that affect the functionality of the membrane as a selective barrier and matrix for enzymes [54]. High concentrations of crude oil or petroleum products lower the activity of superoxide dismutase, an enzyme that removes free radicals in vivo [55]. The result is accumulation of active oxygen free radicals, which attack the DNA, protein, biological membranes, and chloroplast of the cell [56].

The mechanisms by which low concentrations of oil enhance phytoplankton growth are unclear, but enhancements of growth or photosynthetic rates similar to the effects we observed (Figure 1) have been reported in several other studies [13,15,19,23,29,31,57]. The positive effects may be indirect and involve interactions with 
Citation: Li J, Bidigare RR, Laws EA (2017) Effects of Macondo Oil on Phytoplankton from Grand Isle, Louisiana. J Environ Anal Toxicol 7: 468. doi: 10.4172/2161-0525.1000468

Page 4 of 7

\begin{tabular}{|c|c|c|c|c|c|c|c|c|c|}
\hline \multicolumn{10}{|c|}{ Algal Group } \\
\hline & Chlorophytes & Chrysophytes & Cryptophytes & Cyanobacteria & Diatoms & Dinoflagellates & Pelagophytes & Prasinophytes & Prymnesiophytes \\
\hline \multicolumn{10}{|l|}{ Pigment } \\
\hline Alloxanthin & & & $\checkmark$ & & & & & & \\
\hline$\alpha$-carotene & $\checkmark$ & & $\checkmark$ & & & & & $\checkmark$ & \\
\hline$\beta$-carotene & $\checkmark$ & $\checkmark$ & & $\checkmark$ & $\checkmark$ & $\checkmark$ & $\checkmark$ & $\checkmark$ & $\checkmark$ \\
\hline Chlorophyll $b$ & $\checkmark$ & & & & & & & $\checkmark$ & \\
\hline Chlorophyll c & & $\checkmark$ & $\checkmark$ & & $\checkmark$ & $\checkmark$ & $\checkmark$ & & $\checkmark$ \\
\hline Diadinoxanthin & & & & & $\checkmark$ & $\checkmark$ & $\checkmark$ & & $\checkmark$ \\
\hline Diatoxanthin & & & & & $\checkmark$ & $\checkmark$ & $\checkmark$ & & $\checkmark$ \\
\hline Fucoxanthin & & $\checkmark$ & & & $\checkmark$ & & $\checkmark$ & & $\checkmark$ \\
\hline Lutein & $\checkmark$ & & & & & & & & \\
\hline Peridinin & & & & & & $\checkmark$ & & & \\
\hline Prasinoxanthin & & & & & & & & $\checkmark$ & \\
\hline $19^{\prime}$-butanoyloxyfucoxanthin & & & & & & & $\checkmark$ & & \\
\hline $19^{\prime}$-hexanoyloxyfucoxanthin & & & & & & & & & $\checkmark$ \\
\hline Violaxanthin & $\checkmark$ & $\checkmark$ & & & & & & $\checkmark$ & \\
\hline Zeaxanthin & $\checkmark$ & & & $\checkmark$ & & & & $\checkmark$ & \\
\hline
\end{tabular}

Table 1: Distribution of diagnostic pigments in algal groups.

heterotrophic bacteria, suppression of predation [e.g., 58], and changes in the outcome of competition with other phytoplankton species. Several studies, for example, have indicated that diatoms are more tolerant to oil than other classes of phytoplankton $[28,30,34,59]$, although diatoms are sometimes outcompeted by other classes of phytoplankton in the presence of oil $[60,61]$. The impact of oil on diatoms varies between species and as a function of cell size $[15,30,31,34,62]$. The mechanisms that underlie the cell size effects are unclear and may involve surfaceto-volume considerations $[33,63]$ as well as changes in predation pressure [30].

Our pigment results indicate that diatoms dominate phytoplankton communities in coastal Louisiana waters. This result is not particularly surprising. Silicate concentrations in the Mississippi River are roughly $100 \mu \mathrm{M}[64]$, and the molar ratios of silicate to nitrate in the MississippiAtchafalaya combined discharge have averaged 2.0-2.3 since 2000 [65], twice the molar ratio of 1.0 associated with silicate limitation of diatom growth [64]. The positive correlation between oil concentrations and the FUCO/CHLA ratios (Figure 3) most likely reflects acclimation of the diatom community to the physiological effects of the oil and the need to balance the rates of the light and dark reactions of photosynthesis. Fucoxanthin absorbs light strongly at wavelengths of $450-550 \mathrm{~nm}$, whereas chl $a$ absorbs light most strongly at wavelengths of $400-450 \mathrm{~nm}$ and $650-700 \mathrm{~nm}$. Thus, FUCO and CHLA are largely complementary with respect to light absorption, and some adjustment in the characteristics of the light-harvesting antennae of diatoms may well be a response to the presence of oil in the water. To the best of our knowledge, this effect of oil on diatoms has not been reported previously.

\section{Implications}

The results of this study add to the growing base of information on oil effects on phytoplankton. The components of crude oil of greatest concern from the standpoint of toxic effects are the low molecular weight aromatics such as benzene and toluene, which are among the most water-soluble components of oil and hence most likely to find their way into phytoplankton cells, where they may be incorporated into lipids or other components of the cell in sufficient concentrations to upset normal metabolic functions. The contribution to toxicity of compounds of higher molecular weight than alkylnaphthalenes is believed to be very small and probably insignificant in terms of acutely toxic effects [66]. Any mechanism that tends to selectively remove the low molecular weight components of crude oil therefore tends to reduce its toxicity to phytoplankton. The results of our studies of the toxic effects of Macondo oil on coastal phytoplankton therefore tend to overestimate the impact of the oil on phytoplankton because most of the low molecular weight components of the oil dissolved in the water column before the oil reached the surface [67]. Even if the oil had been discharged at the surface, the distance of the spill from the shoreline $(80 \mathrm{~km})$ would have allowed most of the more toxic components to evaporate away before the oil reached the coastal zone. Even in the absence of such weathering effects, our results suggest that any adverse effects on phytoplankton growth rates would be negligible at Macondo oil concentrations less than about $0.6 \mathrm{ppm}$ (Figure 1). At higher oil concentrations the impact on the phytoplankton would likely depend on the composition and physiological condition of the phytoplankton community, as well as other circumstances. In the case of the Deepwater Horizon (DWH) oil spill, for example, a total of 1.4 million gallons of a combination of two dispersants, Corexit ${ }^{\circledR}$ 9500A and Corexit ${ }^{\circ}$ 9527, were applied to the oil that reached the surface. Thus, phytoplankton were actually exposed to a combination of DWH oil and dispersants, and studies by Özhan and Bargu [28] have shown that inputs of Corexit $^{\circ}$ 9500A significantly increased the toxicity of Louisiana sweet crude oil to offshore phytoplankton communities about $100 \mathrm{~km}$ from the mouth of the Mississippi River. Furthermore, addition of nutrients to offshore water samples reduced the inhibitory effects of the oil [28]. The results of our studies of the impact of Macondo oil on coastal diatom communities seem qualitatively very consistent with the studies of Özhan and Bargu [28].

\section{Acknowledgments}

This research was supported by the LSU Office of Research and Economic Development grant 37565 to EAL. We are indebted to Ms. Stephanie Christensen for the pigment analyses. 
Citation: Li J, Bidigare RR, Laws EA (2017) Effects of Macondo Oil on Phytoplankton from Grand Isle, Louisiana. J Environ Anal Toxicol 7: 468. doi: $10.4172 / 2161-0525.1000468$

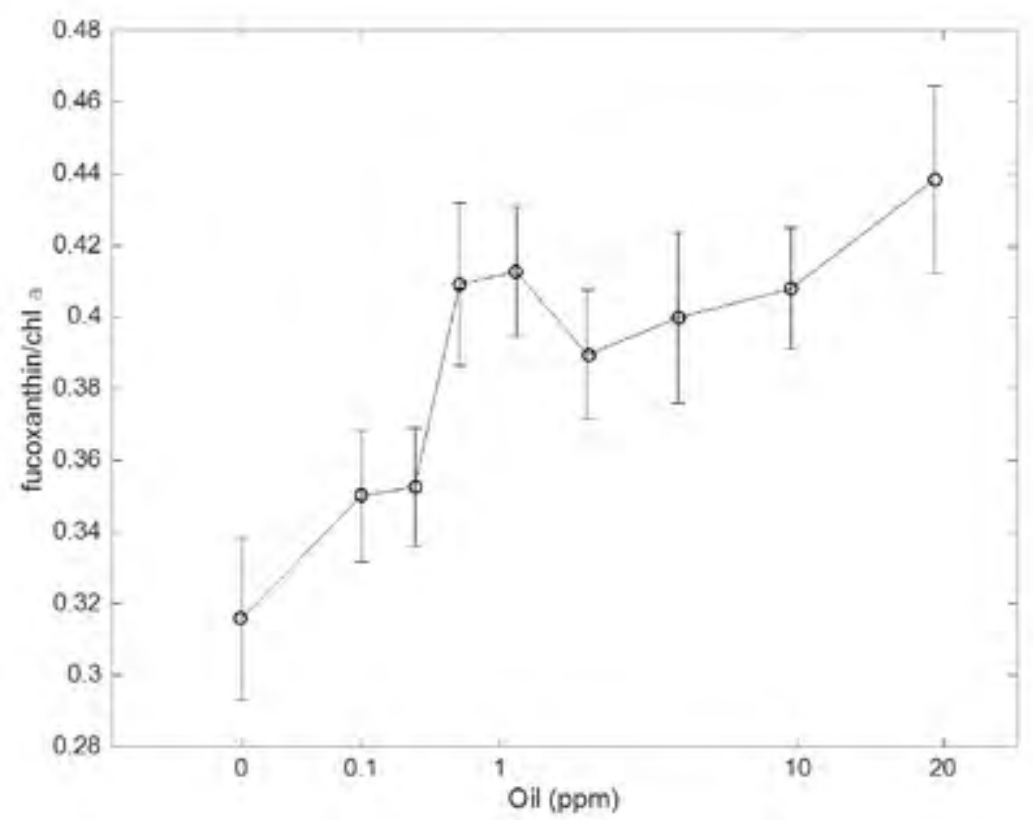

Figure 2: Mean ratios of fucoxanthin to chlorophyll $a$ at end of log-phase growth versus oil concentrations. Error bars are standard errors of mean values.

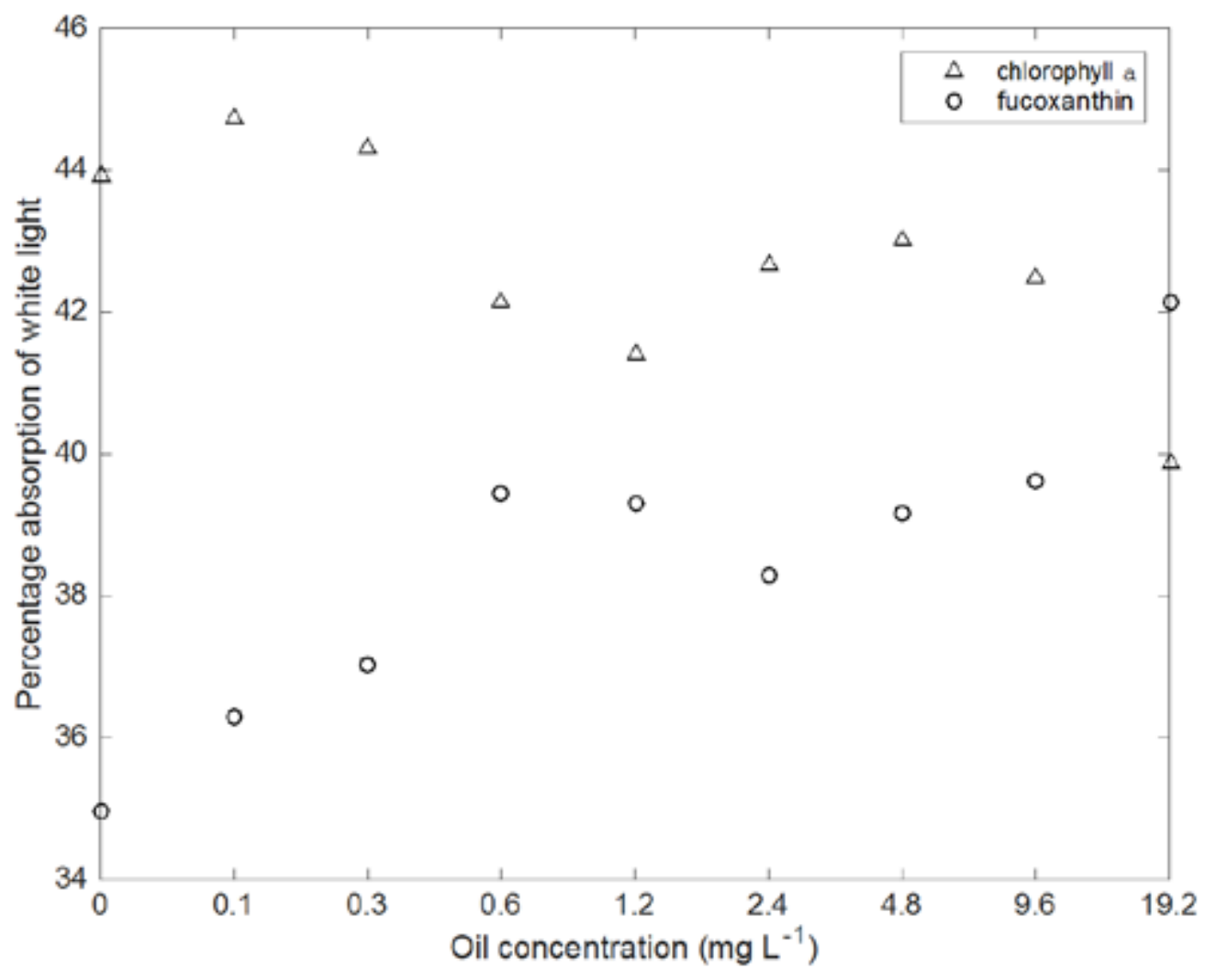

Figure 3: Mean percentages of white light absorbed by chlorophyll $a$ and fucoxanthin versus oil concentrations. 
Citation: Li J, Bidigare RR, Laws EA (2017) Effects of Macondo Oil on Phytoplankton from Grand Isle, Louisiana. J Environ Anal Toxicol 7: 468. doi: 10.4172/2161-0525.1000468

Page 6 of 7

\section{References}

1. NRC (2003) Oil in the Sea III. National Academy Press, Washington, DC.

2. ITOPF (2015) Oil tanker spill statistics 2014. The International Tanker Owners Pollution Federation.

3. Blumer M, Sanders HL, Grassie JF, Hampson GR (1971) An ocean of oil: a small oil spill. Environment: Science and Policy for Sustainable Development 13: 2-12.

4. Krebs CT, Burns KA (1977) Long-Term Effects of an Oil Spill on Populations of the Salt-Marsh Crab Uca pugnax. Science 197: 484-487.

5. Piatt JF, Ford RG (1996) How many seabirds were killed by the Exxon Valdez oil spill. InAmerican Fisheries Society Symposium 18: 712-719.

6. Bowman TD (1993) Bald eagles: after the spill. Alaska Wildlife 25: 13-14

7. Spies RB, Rice SD, Wolfe DA, Wright BA (1996) The effects of the Exxon Valdez oil spill on the Alaskan coastal environment. In American Fisheries Society Symposium, pp: 1-16.

8. Ballachey BE, Monson DH, Esslinger GG, Kloecker K, Bodkin J, et al. (2014) Update on sea otter studies to assess recovery from the 1989 Exxon Valdez oil spill, Prince William Sound, Alaska: US Geological 'Survey Open-File Report 2014-1030. United States Department of the Interior. US Geological Survey, Washington, DC

9. Peterson BJ, Howarth RW (1987) Sulfur, carbon, and nitrogen isotopes used to trace organic-matter flow in the salt-marsh estuaries of Sapelo Island, Georgia. Limnol Oceanogr 32: 1195-1213.

10. Peterson BJ, Howarth RW, Garritt RH (1986) Sulfur and carbon isotopes as tracers of salt marsh organic matter flow. Ecology $67: 865-874$.

11. Kusk KO (1978) Effects of crude oil and aromatic hydrocarbons on photosynthesis of diatom Nitzschia palea. Physiologia Plantarum 43: 1-6.

12. Wolfe MF, Olsen HE, Gasuad KA, Tjeerdema RS, Sowby ML (1999) Induction of heat shock protein (hsp)60 in Isochrysis galbana exposed to sublethal preparations of dispersant and Prudhoe Bay crude oil. Marine Environmental Research 47: 473-489.

13. Karydis M (1979) Short-term effects of hydrocarbons on the photosynthesis and respiration of some phytoplankton species. Botanica Marina 22: 281-285.

14. Ozhan K, Bargu S (2014) Responses of sympatric Karenia brevis Prorocentrum minimum, and Heterosigma akashiwo to the exposure of crude oil. Ecotoxicology 23: 1387-1398.

15. Özhan K, Miles SM, Gao H, Bargu S (2014) Relative Phytoplankton growth responses to physically and chemically dispersed South Louisiana sweet crude oil. Environmental Monitoring and Assessment 186: 3941-3956.

16. Østgaard K, Hegseth EN, Jensen A (1984) Species-dependent sensitivity of marine planktonic algae to Ekofisk crude oil under different light conditions. Botanica Marina 27: 309-318

17. Parab SR, Pandit RA, Kadam AN, Indap MM (2008) Effect of Bombay high crude oil and its water-soluble fraction on growth and metabolism of diatom Thalassiosira sp. Indian Journal of Marine Sciences 37: 251-255.

18. Liu Y, Luan TG, Lu NN, Lan CY (2006) Toxicity of fluoranthene and its biodegradation by Cyclotella caspia Alga. Journal of Integrative Plant Biology 48: $169-180$

19. Dunstan WM, Atkinson LP, Natoli J (1975) Stimulation and inhibition of phytoplankton growth by low molecular weight hydrocarbons. Marine Biology 31: $305-310$

20. Wang L, Zheng B (2008) Toxic effects of fluoranthene and copper on marine diatom Phaeodactylum tricornutum. Journal of Environmental Sciences-China 20: $1363-1372$.

21. Wang L, Zheng B, Meng W (2008) Photo-induced toxicity of four polycyclic aromatic hydrocarbons, singly and in combination, to the marine diatom Phaeodactylum tricornutum. Ecotoxicology and Environmental Safety 71: 465472

22. Soto C, Hellebust JA, Hutchinson TC, Sawa T (1975) Effect of naphthalene and aqueous crude oil extracts on green flagellate Chlamydomonas angulosa. 1. growth. Canadian Journal of Botany-Revue Canadienne De Botanique 53 109-117.

23. Parsons TR, Li WKW, Waters R (1976) Some preliminary observations on enhancement of phytoplankton growth by low levels of mineral hydrocarbons. Hydrobiologia 51: 85-89.

24. Koshikawa H, Xu KQ, Liu ZL, Kohata K, Kawachi M, et al. (2007) Effect of the water-soluble fraction of diesel oil on bacterial and primary production and the trophic transfer to mesozooplankton through a microbial food web in Yangtze estuary, China. Estuarine Coastal and Shelf Science 71: 68-80.

25. Paixoa JF, Nascimento IA, Pereira SA, Leite MBL, Carvalho GC, et al. (2007) Estimating the gasoline components and formulations toxicity to microalgae (Tetraselmis chuii) and oyster (Crassostrea rhizophorae) ernbryos: An approach to minimize environmental pollution risk. Environmental Research 103: $365-374$

26. Mohammady NGD, Chen YC, El-Mahdy AA, Mohammad RF, Mohammady ED (2005) Temporal alterations of Nannochloropsis salina (Eustigmatophyceae) grown under aqueous diesel fuel stress. J Appl Phycol 17: 161-170.

27. Mohammady NGE, Chen YC, El-Mahdy AEA, Mohammad RF (2005) Physiological responses of the eustigmatophycean Nannochloropsis salina to aqueous diesel fuel pollution. Oceanologia 47: 75-92.

28. Özhan K, Bargu S (2014) Distinct responses of Gulf of Mexico phytoplankton communities to crude oil and the dispersant corexit (®) 9500A under different nutrient regimes. Ecotoxicology 23: 370-384

29. Gordon DC, Prouse NJ (1973) Effects of three oils on marine phytoplankton photosynthesis. Marine Biology 22: 329-333.

30. Gonzalez J, Figueiras FG, Aranguren-Gassis M, Crespo BG, Fernandez E, et al. (2009) Effect of a simulated oil spill on natural assemblages of marine phytoplankton enclosed in microcosms. Estuarine Coastal and Shelf Science 83: $265-276$.

31. Huang YJ, Jiang ZB, Zeng JN, Chen QZ, Zhao YQ, et al. (2011) The chronic effects of oil pollution on marine phytoplankton in a subtropical bay, China. Environmental Monitoring and Assessment 176: 517-530.

32. Siron R, Pelletier E, Roy S (1996) Effects of dispersed and adsorbed crude oil on microalgal and bacterial communities of cold seawater. Ecotoxicology 5: 229-251.

33. Sargian P, Mas S, Pelletier E, Demers S (2007) Multiple stressors on an Antarctic microplankton assemblage: water soluble crude oil and enhanced UVBR level at Ushuaia (Argentina). Polar Biology 30: 829-841.

34. Gilde K, Pinckney JL (2012) Sublethal Effects of Crude Oil on the Community Structure of Estuarine Phytoplankton. Estuaries and Coasts 35: 853-861.

35. Hjorth M, Forbes VE, Dahlloef I (2008) Plankton stress responses from PAH exposure and nutrient enrichment. Marine Ecology Progress Series 363: 121 130

36. Varela M, Bode A, Lorenzo J, Alvarez-Ossorio MT, Miranda A, et al. (2006) The effect of the "Prestige" oil spill on the plankton of the N-NW Spanish coast. Ma Pollut Bull 53: 272-286.

37. Vargo GA, Hutchins M, Almquist G (1982) The effect of low, chronic levels of no 2 fuel oil on natural phytoplankton assemblages in microcosms: 1 . species composition and seasonal succession. Marine Environmental Research 6: 245-

38. Reddy CM, Arey JS, Seewald JS, Sylva SP, Lemkau KL, et al. (2012) Composition and fate of gas and oil released to the water column during the Deepwater Horizon oil spill. Proc Natl Acad Sci U S A 109: 20229-20234.

39. Hamam SEM, Hamoda MF, Shaban HI, Kilani AS (1988) Crude oil dissolution in saline water. Water Air and Soil Pollution 37: 55-64.

40. Guillard RR, Ryther JH (1962) Studies of marine planktonic diatoms. I. Cyclotella nana Hustedt, and Detonula confervacea (cleve) Gran. Can J Microbiol 8: 229-239.

41. Guillard RRL (1975) Culture of phytoplankton for feeding marine inveretebrates. In Smith WL, Chanley MH, eds, Culture of Marine Invertebrate Animals. Plenum Press, New York, pp 26-60.

42. Laws EA, Bannister TT (1980) Nutrient- and light-limited growth of Thalassiosira fluviatilis in continuous culture, with implications for phytoplankton growth in the ocean. Limnol Oceanogr 25: 457-473.

43. Harding LW, Prezelin BB, Sweeney BM, Cox JL (1982) Diel oscillations of the photosynthesis-irradiance $(P-I)$ relationship in natural assemblages of phytoplankton. Marine Biology 67: 167-178. 
Citation: Li J, Bidigare RR, Laws EA (2017) Effects of Macondo Oil on Phytoplankton from Grand Isle, Louisiana. J Environ Anal Toxicol 7: 468. doi: 10.4172/2161-0525.1000468

44. Harrison WG, Platt T (1986) Photosynthesis-irradiance relationships in polar and temperate phytoplankton populations. Polar Biology 5: 153-164.

45. Aurand DV, Coelho GM, Sowby M, Bragin GE, Clark JR, et al. (2001) Making, Measuring, and Using Water-accommodated Fractions of Petroleum for Toxicity Testing. 2001 International Oil Spill Conference, pp: 1269-1274.

46. Kain JM, Fogg GE (1958) Studies on the growth of marine phytoplankton.1. Asterionella japonica gran. Journal of the Marine Biological Association of the United Kingdom 37: 397-413.

47. Kain JM, Fogg GE (1958) Studies on the growth of marine phytoplankton. 2. Isochrysis galbana parke. Journal of the Marine Biological Association of the United Kingdom 37: 781-788.

48. Bidigare RR, Van Heukelem L, Trees CC (2005) Analysis of algal pigments by high-performance liquid chromtography. In: Andersen RA (ed.), Algal Culturing Techniques. Academic Press, New York, USA, pp: 327-345.

49. Wright SW, Jeffrey SW, Mantoura RFC, Llewellyn CA, Bjørland T, et al. (1991) Improved HPLC method for the analysis of chlorophylls and carotenoids from marine phytoplankton. Mar Ecol-Prog Ser 77: 183-196.

50. Fujiki T, Taguchi S (2001) Relationship between light absorption and the xanthophyll-cycle pigments in marine diatoms. Plankton Biology \& Ecology 48: 96-103.

51. Bidigare RR, Ondrusek ME, Morrow JH, Kiefer DA (1990) In vivo absorption properties of algal pigments. Proceedings of the International Society for Optical Engineering 1302, Ocean Optics X: 290-302.

52. Letelier RM, Bidigare RR, Hebel DV, Ondrusek M, Winn CD, et al. (1993) Temporal variability of phytoplankton community structure-based on pigment analysis. Limnol Oceanogr 38: 1420-1437.

53. Walker JD, Seesman PA, Colwell RR (1975) Effect of South Louisiana crude oil and no 2 fuel oil on growth of heterotrophic microorganisms, including proteolytic, lipolytic, chitinolytic and cellulolytic bacteria. Environmental Pollution 9: 13-33.

54. Sikkema J, de Bont JA, Poolman B (1995) Mechanisms of membrane toxicity of hydrocarbons. Microbiol Rev 59: 201-222.

55. Winston GW, Digiulio RT (1991) Prooxidant and antioxidant mechanisms in aquatic organisms. Aquatic Toxicology 19: 137-161.
56. Singh AK, Kumar HD (1991) Inhibitory effect of petroleum oil on photosynthetic electron transport system in the cyanobacterium Anabaena doliolum. Bulletin of Environmental Contamination and Toxicology 47: 890-895.

57. Wang $Y$, Tang $X$, Li Y, Liu Y (2002) Stimulation effect of anthracene on marine microalgae growth. Ying Yong Sheng Tai Xue Bao 13: 343-346.

58. Miller MC, Alexander V, Barsdate RJ (1978) Effects of oil spills on phytoplankton in an arctic lake and ponds. Arctic 31: 192-218.

59. Gonzalez J, Fernandez E, Figueiras FG, Varela M (2013) Subtle effects of the water soluble fraction of oil spills on natural phytoplankton assemblages enclosed in mesocosms. Estuarine Coastal and Shelf Science 124: 13-23.

60. Harrison PJ, Cochlan WP, Acreman JC, Parsons TR, Thompson PA, et al (1986) The effects of crude oil and corexit 9527 on marine phytoplankton in an experimental enclosure. Marine Environmental Research 18: 93-109.

61. Nomura H, Toyoda K, Yamada M, Okamoto K, Wada M, et al. (2007) Mesocosm studies on phytoplankton community succession after inputs of the water-soluble fraction of Bunker A oil. La Mer 45: 105-116.

62. Adekunle IM, Ajijo MR, Adcofun CO, Omoniyi IT (2010) Response of four phytoplankton species found in some sectors of Nigerian coastal waters to crude oil in controlled ecosystem. International Journal of Environmental Research 4: 65-74.

63. Echeveste P, Agusti S, Dachs J (2010) Cell size dependent toxicity thresholds of polycyclic aromatic hydrocarbons to natural and cultured phytoplankton populations. Environmental Pollution 158: 299-307.

64. Turner RE, Qureshi N, Rabalais NN, Dortch Q, Justia D, et al. (1998) Fluctuating silicate:nitrate ratios and coastal plankton food webs. Proc Natl Acad Sci USA 95: 13048-13051.

65. Cardona Y, Bracco A, Villareal TA, Subramaniam A, Weber SC, et al. (2016) Highly variable nutrient concentrations in the Northern Gulf of Mexico. DeepSea Research Part I. i. Topical Studies in Oceanography 129: 20-30.

66. NRC (1985) Oil in the Sea: Inputs, Fates, and Effects. National Academy Press, Washington, DC.

67. Melvin AT, Thibodeaux LJ, Parsons AR, Overton E, Valsaraj KT, et al. (2016) Oil-material fractionation in Gulf deep water horizontal intrusion layer: Field data analysis with chemodynamic fate model for Macondo 252 oil spill. Mar Pollut Bull 105: 110-119. 